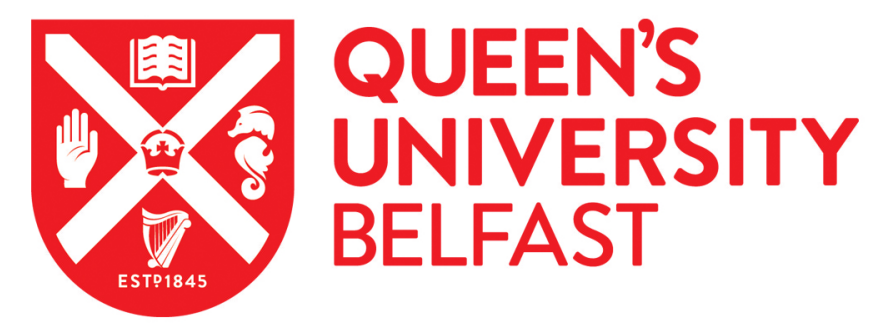

\title{
Father Identity, Involvement and Work-Family Balance: An In-depth Interview Study
}

McLaughlin, K., \& Muldoon, O. (2014). Father Identity, Involvement and Work-Family Balance: An In-depth Interview Study. Journal of Community and Applied Social Psychology, 24(5), 439-452.

https://doi.org/10.1002/casp.2183

Published in:

Journal of Community and Applied Social Psychology

Document Version:

Peer reviewed version

Queen's University Belfast - Research Portal:

Link to publication record in Queen's University Belfast Research Portal

\section{Publisher rights}

Copyright (C) 2014 John Wiley \& Sons, Ltd.

This is the peer reviewed version of the following article: McLaughlin K. and Muldoon O. (2014), Father Identity, Involvement and Work-Family Balance: An In-depth Interview Study, J. Community Appl. Soc. Psychol., 24, pages 439-452, which has been published in final form at http://onlinelibrary.wiley.com/doi/10.1002/casp.2183/abstract. This article may be used for non-commercial purposes in accordance with Wiley Terms and Conditions for Self-Archiving.

\section{General rights}

Copyright for the publications made accessible via the Queen's University Belfast Research Portal is retained by the author(s) and / or other copyright owners and it is a condition of accessing these publications that users recognise and abide by the legal requirements associated with these rights.

\section{Take down policy}

The Research Portal is Queen's institutional repository that provides access to Queen's research output. Every effort has been made to ensure that content in the Research Portal does not infringe any person's rights, or applicable UK laws. If you discover content in the Research Portal that you believe breaches copyright or violates any law, please contact openaccess@qub.ac.uk. 


\begin{abstract}
:
Work and family roles have changed considerably in the past number of decades. Fathers are now expected to fulfill the role of 'new father' which involves actively caring and sharing in child rearing, and at the same time maintain commitment to their occupational role. As a consequence men are subject to the same pressure that women were when they initially entered the workplace decades ago and indeed still are today. This study aims to explore the meanings father attach to their life roles, how these meanings influence behavior within these roles, and how they negotiate the demands of these roles. In- depth interviews were carried out with fifteen fathers and the results were analysed adhering to the principles of Grounded Theory. The findings show the variability among fathers in both their commitment to fathering and the meanings they attach to that role. A significant tension between new fatherhood ideals and actual fathering practices is also apparent. These findings are discussed drawing upon traditional definitions of masculinity and wider occupational and cultural influences.
\end{abstract}


Father Identity, Involvement and Work Family Balance: An In-depth Interview Study

Men’s and women's family and occupational roles have shifted considerably over the past number of decades in Western cultures. In particular the widespread entry of women into the labor market, together with the feminist agenda over the past four decades, has served to challenge the assumption that women's primary adult role is that of caregiver responsible for both home and family (Shelton \& John, 1996). As a consequence, but perhaps more slowly, societal expectations of men's involvement in the home and as parents has also changed (Ranson, 2012). How fathers respond to these changing lifestyle norms has become a huge focus of research for academics, practitioners and policy makers during the last two decades (Henwood \& Procter, 2003). These questions are not just academic, father involvement in children's lives and the quality of father- child relationship is an important predictor of both adolescents and father’s health (Janzen \& Kelly, 2012).

Given the growing acknowledgment of the benefits of fathers' involvement in childrearing for children, this paper focuses on how men experience family life and their role as parent, as well as the factors they believe foster or hinder this involvement. Though there have been marked changes in labour force participation, gendered constructions of domestic and occupational roles remain remarkably resistant to change (McLaughlin, Muldoon \& Moutray, 2010). So for example, though fathers are spending more time caring for their children, and are more visibly involved with their children than fathers were in the past (Pleck \& Masciadrelli, 2004), this has not displaced the breadwinning requirements of fatherhood (Daly \& Palkovitz, 2004). And whilst women's movement into the labour market destabilized the breadwinning role as a basis for male identity, mothers much more than fathers are likely to adjust their working conditions to accommodate family life (Luarijssen \& Glorieux, 2013). Consistent with 
this evidence, Mannino \& Deutsch (2007) argue that the progression of women in both economic and political spheres has not been matched by equivalent changes within the home, with household labour and childcare remaining distributed unequally along gendered lines.

The contemporary rhetoric around fatherhood, and media and cultural representations of the 'new father' as one that is active in caregiving and involved with his children looms large (Ranson, 2009). However levels of involvement in child rearing for fathers remain consistently lower than that of mothers (Henwood \& Proctor, 2003) and available evidence indicates that fathers spend significantly less time than mothers caring for children (Craig \& Bittman, 2004). Of course the changes in the gender composition of the labor market have co-occurred with the growth of powerful multinational employers, the demise of trade unionism, and life-long employment opportunities. It is within this more competitive job market, the long hours work culture has taken hold (Gregory \& Milner, 2009). On average UK fathers with children under 14 years old work for 46 hours per week (Cousins \& Tang, 2004) and quite frequently late nights and weekends. Lewis and Lamb (2006) evidenced that more than 33 percent of men regularly work in paid employment more than 48 hours per week, and 12 percent work over 60 hours. Long hours work culture continue to predominate particularly in traditionally male professions and over-working is often considered normative within these occupational settings (Cha, 2013). As a consequence, it would appear that that even amongst professional fathers who endorse new representations of fatherhood, actual fathering practices are fitted around long working hours and the demands of the workplace (Halford, 2006). This reality perhaps reflects the lingering belief that being a good father is synonymous with being an effective provider (Coltrane, 2004). This range of occupational and cultural influences on normative expectations of fathers as engaged 
and 'hands on', on the one hand and as breadwinners and providers on the other, we argue may contribute to the gap between fatherhood ideals and actual fathering practices.

Crucial to how fathers negotiate this gap are the meanings that individuals attach to particular roles. These meanings help to establish identities (Henley \& Pasley (2005), which in turn have the ability to direct behaviour (Reicher, 1984) particularly in those contexts where the identity is salient - in this case the family context. Thus a 'father identity' is defined as an ‘internalized set of father role expectations’ (Stryker, 1987), which are seen to influence behavior within that role. The social identity approach (see Haslam, 2004) has been used to illustrate both the amount and manner of father involvement, asserting that fathers' involvement with children is influenced by the meanings and importance they attach to their fathering role (Olmstread, Futris \& Pasley, 2009). For example aspects of a fathers identity; namely competence, satisfaction and investment in the father role, predicts involvement with children post divorce. And this engagement as a father can be mediated by the views of significant others, most notably the child(ren)’s mother (Matta and Knudson-Martin, 2006). Pasley, Futrix and Skinner, (2002) found that men who believe that their wives view their parenting favorably, thus bolstering their identity tend to be more involved with their children.

\section{The Present Paper}

Although tension between work and family roles is increasing for men, to date few studies have investigated work family conflict specifically amongst men (Harrington et al, 2011). We suggest that one source of this tension may well be the idealised notions of fatherhood that creates expectations about occupational and family roles that are difficult to meet. A second source of tension is likely to be related to the influence of cultural norms around appropriate 
male and female behaviour. The expectations placed on fathers, and those they place on themselves are inherently gendered, with constructions of ‘working fathers' (and ‘working mothers') prevailing over those of 'working parents'. So alongside the cultural representations of the 'new father or 'new man' that may influence contemporary parents are the long standing and traditional representations of masculinity and fatherhood. And of course, there is considerable variation between fathers and parents in terms of how they perceive their family role, identities and responsibilities, and these too are likely to shape expectations (Este \& Tachable, 2009).

Given the shifting rhetoric around fatherhood (Ranson, 2012), the relative dearth of research in this area, as well as the degree to which fathers must negotiate competing occupational and family roles, the need for an in-depth approach became self-evident. Given our critical concern with the paradoxes evident in the current literature, a key focus became fathers personal expectations of their role. Cook et al (2005) argue convincingly that these expectations have greater explanatory power in terms of father involvement than attributes such as gender role ideology as they have the capacity to reveal psychological processes underpinning involvement. Our attempt to access these processes and examine them more fully, was to embed our interview conversations fully in the everyday lives of fathers who were negotiating competing demands of work and family life. By embedding our interviews with fathers in this way, it is possible to move our examination away from abstract notions of traditional and modern conceptualisations of fathers to a more everyday understanding upon which men’s identities are built (Haslam, 2004; O’Brien, 2005). Thus using a qualitative approach was consistent not only with the aims of the study but also compatible with an approach which sought to critically appraise the apparent mismatch between new constructions of fatherhood, increasing evidence of men’s 
experience of work family conflict (Janzen, \& Kelly, 2012) and the ongoing and persistent nature of occupational and domestic division of labour (Laurijssen, \& Glorieux, 2013).

\section{Method}

Study design

Prior to commencement of the study ethical approval was obtained from the School of Psychology Ethics Committee at Queen’s University Belfast. Interviews were carried out with fathers in full time employment and the data were analysed adhering to the principles of Grounded Theory. Grounded theory is a research method developed by Glaser and Strauss (1967), which consists of systematic yet flexible guidelines for collecting and analysing qualitative data (Charmaz, 2006). It is a process of engaging in close and detailed examination of qualitative data so that theoretical considerations are both stimulated and disciplined (Muldoon, McLaughlin \& Trew, 2007).

\section{Participants}

Fifteen fathers in paid employment agreed to participate in in-depth interviews. The sample included participants from a range of socioeconomic backgrounds, for example, company managers, university lecturers, housing officers and both skilled and unskilled manual workers. All of the participants were white and resided in towns or rural areas in Northern Ireland. Thirteen of the participants were married, two were cohabitating, and one was widowed. The sample included participants aged between 23 years and 60 years old, thus encompassing varying family stages. (For more demographical information see table one). 
A key component of grounded theory is Theoretical Sampling which refers to the process of data collection for generating theory whereby the researcher collects, codes and analyses the data, deciding what data to collect next and where to find it (Marcellus, 2005). Participants were theoretically sampled to include fathers across the age and socio-economic spectrum via friends, family and occupational networks. They were first sent a letter explaining the nature and purpose of the interview and advised that the researcher would follow up with a phone-call. All potential participants were telephoned and if agreeable, informed consent was obtained orally. A suitable time and venue was then arranged. All interviews were carried out by the first author, and lasted between one and two hours. Interviews were conducted at a venue of the participant's choice (either their home or workplace), were recorded and transcribed verbatim.

The Interview Process

This research attempted to overcome the limitations of previous research by allowing fathers themselves to articulate the meanings and expectations they attach to their life roles, i.e. what they thought makes a good father, a good employee/worker and a good husband. Fathers were asked to provide examples of when work and family intersected, the importance they attributed to the various roles in their lives and how they combined the demands of work and family life. In line with the principles of Grounded Theory (Glaser \& Strauss, 1967), the guide was not strictly adhered to thus allowing fathers to discuss issues most important and relevant to them. It should be noted that in GT the process of analysis begins at the same time as data collection. The 'constant comparative process' is a term that has been coined to refer to the ongoing process of referral and identification of similarities and differences between emerging 
categories (Glaser \& Strauss, 1967), and can be seen as a cornerstone of GT (Marcellus, 2005). Thus the schedule evolved as the interviews and analysis progressed and having interviewed the first participants, the need to include an additional question to tap into multiple aspects of identity became apparent. This question asked men to detail their ideals of father, partner and worker. Similarly as analyses continued it became apparent that interviews with the final three fathers were providing confirmatory information and the categories generated from the data were saturated.

\section{Data Analysis}

After the transcripts were read and re-read, they were divided into segments and numbered making it easier to find them later in the process. Having divided the transcript into segments, the next step was to organise each segment into meaning units. A meaning unit is the smallest piece of information that can make sense on its own, it can be a full sentence or a one word answer. Each meaning unit was then transferred onto an index card in the third person, preserving the terminology of the participant as much as possible. Analysis proceeded as new meaning units were generated, entered on separate cards and placed on a large flat surface. When units were amalgamated that seemed to reflect a similar theme, the cards were placed together. If necessary a unit was placed in more than one category, a process known as 'open categorisation'. When similar meaning units accumulated (6-8 similar utterances) an umbrella term which encompassed all of the meaning units was generated which is referred to as a category. When a category contained many references, was precisely defined and when it was clear whether or not a new meaning unit should be included in it, it was deemed saturated (Lincoln \& Cuba, 1985). 
The next stage of the analysis involved movement from the descriptive to the conceptual. At this point, there were many defined categories to describe the data. Each category description was reconsidered and thus the generation of higher order higher order categories began. This stage is known as axial coding (Strauss \& Corbin, 1998) which facilitates conceptual analysis and moves beyond the participants' terminology to make inferences and develop theories. This is not only aided by the researchers existing knowledge but by the use of memos, which are kept throughout the GT process.

\section{The Verification Process}

In addition to a clear audit trail which provided a transparent description of the whole research process (Lincoln \& Cuba, 1985), the analytic process was verified by the second author after the first author coded all of the data. Once initial analysis was complete, the second author tracked the analysis and re-assessed the logic of the initial categories developed at each stage of the analytic process. Categories were finalized through a process of negotiation, where viewpoints differed between the two authors, categories were re-evaluated, through the use of memos, original meaning units' piles and reference to the literature. The final stage of the Grounded Theory process is selective coding which refers to selecting the core category, relating it to other categories, confirming those relationships and building those categories that need further development (Strauss \& Corbin, 1998).

Member checking was the second crucial verification process and is a central way of establishing credibility in qualitative research (Lincoln \& Cuba, 1985). Participants were sent a summary of the findings and asked to comment on any issues that specifically applied to them, or that did not apply to them. Whilst all of the fathers reported that they found the results very 
interesting, four included comments with the returned written summary of results, which were anonymous, so it can perhaps be presumed that respondents were free to be open and frank which validated the analysis and interpretation.

Results

Three categories were generated from the data:

1. Providing AND being there: on being a 'traditional' and a 'new' father.

2. Normative understandings of gender, fatherhood and worker.

3. Fathers Perspectives on the Ups and Downs of Combining Work and Family.

1. Providing AND being there: on being a 'traditional' and a 'new' father

This first category includes all of the attributes participants believed constituted a good father. Whilst some of the answers were more in line with traditional role expectations, there was also evidence of new fathering whereby good fathers were seen to be spending time with children and caring for them. The content of this category then can be sent to relate to the diverse and competing expectations of fatherhood.

Our participants believed that being a good father involved a number of attributes. Traditional expectations were often embedded in the perceived social and economic realities for men and women. The role of provider was deemed an essential requisite of a good father, and was viewed as highly significant:

“A good provider, someone who can provide for their family, first and foremost.” \#6

The roles of protector and disciplinarian were also considered important, again in line with traditional expectations of fatherhood. Typical statements reflecting this were: 
"If a parent can get through to his children, here is what's right and here is what's wrong ...maybe you would be a good father if you brought them up to that level, teach them a bit of respect." \#2 “...Strict, and when you tell them something, they know that you mean it.” \#4

In addition to this traditional view, some fathers had definitions which highlighted emotional involvement and making time for their children. Take for example the following two quotations:

“, you have to make five minutes now and then ...You have to be prepared to listen and to try and go down to their level and just do your best and try and keep calm, it is not always easy.” \#1

"I think a father needs to be there for his wife and for his children always, you know morning, noon and night, and I think every father needs to take an active part in bringing up the children and looking after them and all the physical aspects as well as love, care and support and all the emotional aspects.” \#2

A number of points are worthy of note from these quotations. First it would appear that engaging with children 'on their level' can be challenging for fathers. Second, even those fathers who are more emotionally engaged see this as a time limited activity, 'making five minutes now and then' and third these more engaged fathers continue to define a good father with reference to the mother, suggesting a continued level of traditional family relations. This can be further verified when we look at the meanings fathers attach to a good husband. Some of the fathers described how contributing more to childcare and domestic labour would make for a better husband, whilst continuing to assume that the responsibility for housework still rests with the mother. Statements reflecting this were: 
"I could probably be a better husband by giving her more of a hand with the wains." \#3

“...Also like, when you have a young family you have to be prepared to do housework for her, you know give her a hand to hoover or whatever." \#4

However reflective of the variation within the data, some of the men described fathering as more of a process of negotiation between mother and father, largely determined by childcare priorities, work schedules and subject to change from day to day:

"Say if one of them are sick, it will be a balance between whose work priorities that day or for the next few days will take precedence, and because my wife would work with young people in very vulnerable situations, her work will always in my mind take precedence over mine.” \#12

In discussing what they felt was a good father, participants often compared themselves to others. Some participants reflected on their own relationship with their fathers and how things were for them growing up. What participants felt constituted a good father was often influenced by their own experiences as a child. Two fathers discussed negative aspects of their own childhood and how these experiences motivated their parenting in particular directions, one to be a better provider, and another to be more involved with his children than their own fathers had been. Participants also compared themselves to other fathers that they knew.

Participant \#8 illustrates this process via the favorable comparison between him and an old acquaintance who works 14 hour days:

"One of them is an engineer and he works a $14 \mathrm{hr}$ day and so he is at a disadvantage to begin with. He talks about having quality time with his child when he is there but that is a load of balls you have to be there, you have to show them a bit of example, spend time with them and look after them...” \#8 
“I think one of things I wouldn't like to be is these Sunday dads, you know, it's like they work and golf and do everything during the week and then on Sunday they give their wife a lie in, they look after the kids for a couple of hours or take them to the pool, you know or cook the dinner, I wouldn't like to be like that but I certainly know a lot of people like that." \#11

For these fathers rather than imitate or compensate for their own fathers, they are using peers as models in developing their father identities, consistent with the findings of Daly (1993). It is also worth noting that, in marked contrast to the findings on the detrimental effects of intergenerational definitions of motherhood on women or to wider definitions of good mothers (Nicolson, 1996), these social comparisons served to underline their efforts as fathers in a positive light and were used by participants to reflect a positive view of themselves as fathers.

2. Normative understandings of gender, fatherhood and worker.

The second category, related to participants normative understandings of fatherhood and how they were specifically related to gendered notions of the role of men and women in the domestic and occupational arena. Whilst the first category could be seen to be related to participants' own expectations of fatherhood, this category specifically included material that was related to wider occupational and cultural parameters of parenting practices. The category includes instances where participants discuss how being in paid employment is intertwined with being a father and report no difficulties; and where tension and difficulties occur, with participants reporting the incompatibility of new fatherhood ideals and traditional definitions of masculinity. 


\section{$\underline{\text { Parenting and masculinity: going hand in hand together }}$}

So, some of our participants viewed the role of a good father as being provider. In these instances being in paid employment was viewed as synonymous with being a father and a husband. 'I would be a good worker first of all, but in that I am being a good father as I am providing' \#6. Another father reported how not being employed would affect his children more than being in work, again illustrating the interdependency of the roles for men. He stated, 'If I hadn't any work it would probably affect them more.' \#3

These quotes illustrate how these two participants view their occupational and parenting roles as interdependent and very much compatible with each other. They also convey the message that father identity is very much about the provider role first which is in line with previous research (Daly \& Palkovitz, 2004). This presentation of fatherhood as requiring occupational involvement can also be seen as fathers strategically protecting themselves from a charge of not spending enough time with their children given the widespread acceptance of the 'new father' ideal also evident throughout our interviews (see theme 1)

Consistent with this position these respondents did not report any conflict between their work and family roles. These fathers enjoyed control over their roles and viewed their parenting contribution as optional. Typical of this position were statements such as 'I quite enjoy it (parenting) when I have the time' \#10, and 'I would have no bother at all' \#7.

\section{$\underline{\text { Parenting versus masculinity: tension and sacrifice }}$}

Other respondents discussed sharing childcare with their partners. These fathers had a more demanding set of criteria around what makes a good father and reported that they were highly committed to equal parenting. The results suggested the more involved the father was in 
parenting, the more his sense of work life balance tended to waver. The mental strain due to concern over competing demands was frequently alluded to. The views of these respondents were in marked contrast to those with more traditional expectations of the fathering role. For instance, fathers reported:

"You just have to do it, you just have to get on with it, obviously the children have to come first. You have to make them blend in, sometimes you have to make sacrifices, other times it works out alright...it is not easy on the mind either”. \#1

"You know you get up in the morning and I have to get the wains ready, get them fed and get them out and then you are coming to work and they are pulling at you every bloody direction and then you go home and then you are pulled in different ways. It is difficult, Jesus Christ like everything it is difficult..., you are pulled in every bloody direction.” \#8

The use of language in these latter two quotes is particularly interesting. These men talk of juggling and blending things, and making sacrifices. Consequently, their views are strongly reminiscent of much of the literature documenting women's views of combining paid employment and motherhood (Yavas et al, 2008 ). They are also consistent with Aumann et al (2011) who more recently have coined the phrase the 'new male mystique' whereby men are now under pressure, not only to be the primary provider but also to be the involved and loving father. Thus, according to Aumann et al (2011) they are subject to the same pressure that women were when they initially entered the workplace decades ago, and indeed still are today.

A second notable area of disequilibrium for men was the incompatibility of new fatherhood ideals with traditional definitions of masculinity. This created a tension for respondents when they tried to translate their parenting intentions into behaviors.

One man when asked what he thought a good father was, he succinctly remarked: 
"There is a question. I think a lot of people know the answer to that question, it is just putting into practice is the problem...”\#1

More tellingly other participants stated that sharing of parenting and childcare duties would threaten their stereotype of themselves as a man (here referenced through a perceived inability to face his mates were he to do 'what a woman would have to do'). A second father articulated the sense of violating of norms he would experience were he to push 'the trolley about the supermarket' which he though would also reduce his sense of shared identity with his friends.

“...I don't think men are prepared to accept the discipline of doing what a woman would have to do within a household environment, ...They would just say, no way that is not for me, how could I go to the pub and drink with my mates after that." \#1

"I would feel a bit of a pansy pushing the trolley about the supermarket, I mean none of my friends do it." \#13

Here then the incompatibility of new fatherhood ideals and traditional definitions of masculinity were readily apparent as was a keen reluctant on the part of these fathers to behave contrary to traditional gender roles for fear of negative repercussions (Prentice \& Carranza, 2002). Where a gap between the modern ideal of fatherhood and actual performance was located, respondents presented this as justifiable in a number of ways. For instance women were described as being more suited for childcare and domestic labour, and the gendered division of parenting responsibility was presented as a personal choice made knowingly by couples. Take for example the following description of the innate abilities of women and men presented by one respondent -acknowledging the contribution of mothers on the one hand, whilst simultaneously presenting it as beyond the capability of men and as effortless for women: 
"I think women have greater organisational skills than men, for example a mother can be at home and she can be cooking a lunch, she can have 2/3 pots on boiling.... And she can manage everything because I think mothers have this skill whereby they can do three or four things simultaneously whereas men can't.... A man can only do one thing at a time, I think it is an inbuilt thing because of the nature of motherhood, that there is this protective element that women can do this.” \#9

"I just think it is made easier for women by the workplace. You know the reality of my job is if someone wants work done I need to go and do it, otherwise someone else will -I can't afford in the present climate to turn my nose up at work.” \#13

Interestingly however, societal structures and organizations were implicated as constraining choices. One father felt that government and employers should provide guidance and support for fathers to be at home stating: 'So I think if you have a couple or three young children, maybe organisations need to look more at the mother's need for the father to be there at times' \#2. It is of course interesting that this comment, whilst orienting to progressive change for families and fathers, presents without any sense of irony, the mother as the primary carer and the father to be there 'at times'.

3. Fathers Perspectives on the Ups and Downs of Combining Work and Family.

Participants reported enjoying the benefits of combining work and family roles and also instances where conflict occurred. Our orientation here in the first instance to the benefits of combing work and family roles represents an important element of this category, orienting as it does to the perceived benefits of fatherhood for men and moving beyond the notion that 
combined parental and family roles are necessarily problematic. That said, fathers outlined the perceived costs to being a working father identifying negative emotional spillover and the potential detrimental impact of work on their relationships with their children.

$\underline{\text { Work-family integration - benefits and rewards }}$

Fathers interviewed placed value on their role as father and discussed how the more they became involved in the caring for their children, the more they enjoyed it. Participants viewed fatherhood as having a bidirectional quality as well as being a reciprocal process where fathering behaviour enhanced one's sense of being a good father. For example, in some cases being a father represented a sense of personal fulfilment and enjoyment at establishing an emotional connection with your children and the benefits that this brings. Whilst respondents reported that becoming a father was challenging, as the quote below indicates they had not expected the positives that ensued:

"I never had anything like that to do before as I was the youngest in my family. But after I became competent, I actually enjoyed it you know, I enjoyed doing things for them and I felt needed and I really liked it.” \#9

In addition to changing their outlook and experience of life, respondents believed others’ perceptions of them changed when they became fathers. One participant discussed how in his opinion being a father changed a work colleague’s perception of him. In direct contrast to the perceived negative consequences from colleagues that are sometimes reported by women who become mothers (Nicolson, 1996), he believed that he was perceived as being more responsible and mature since becoming a father. This also highlights the positive responses that men 
encounter in occupational settings when they behave in line with their traditional gender roles. He stated,

“I don't know, but since I, we've had the wains, the boss seems to rely on me more, it's like he knows I have them to support and I am more reliable and dependable now.” \#5

Positive emotional spillover between work and family life was also highlighted as a benefit of combining occupational and parenting roles. For example one father stated:

"I suppose the only positive thing, I think work is good for you, work is good for you as a person, for your self esteem, for your confidence everything, so I think work makes you a more comfortable happier person, which then generalises to your family.” \#12

\section{$\underline{\text { Work family conflict - sacrifice and spillover }}$}

On the other hand, men also articulated clear negative emotional spillover from work to family in particular. This 'kick the cat syndrome', which we have not seen described in the literature previously was viewed by men as inevitable. A statement reflecting this was:

"On the emotional level, you take it out on them depending on the kind of day you have had. But we all do that, and it is not just this job, say a man out laying bricks all and he comes home and he is soaking, of course he is going to take it out on the wife." (laughing) \#8

Perhaps because of these difficulties that men encountered, respondents also articulated a perceived lack of support for fathers. The lack of workplace support was also highlighted with men discussing how they had to take a lot of work home with them which would affect their family life or that it was difficult for them to get time off. One man mentioned how he believed that the possibility of taking a day off to attend to family responsibilities was just not an option. 
It is worth noting that this quote illustrates how behaving against traditional gender norms can provoke negative reactions in the workplace:

He stated,

“I can't really take days off to see to the children, my boss would take a long look at me if I asked him for time off for that." \#10

This lack of organizational support reportedly had a detrimental impact on father child relations. Fathers reported how working long hours has a negative impact on their relationship with their children. Some of the fathers believed that the mother enjoyed a much closer relationship with the children than they did, which they put down to them working long hours. For instance they remarked:

“All you have to do is notice who the wains want when they are sick, it is Maria..." \#10 "She knows more about them, about their schoolwork and their friends whereas I would have to ask all these questions...” \#6

The challenges that men face when trying to fulfill their work and fathering roles become all the more apparent in light of the current economic downturn. Against this backdrop, fathers feel they have no choice but to take the work when they can get it:

"She would usually be the one that would have to take off if they were sick or anything like that. I wouldn't have any problem with taking off work myself but nowadays you have to take the work when you can get it, we are under severe pressure at the minute, the work just isn't out there." \#13

It is not surprising then that fathers highlighted the scarcity of work family policies and the pressure that they feel not only to provide for their family but to work long hours: 
"I often see myself not getting in to 8.00 at night and still maybe having more stuff to do. You see, they pay a lot of money and boy do they look for a return. I have no option but to do it, if I don't they will get someone else who will.” \#15

"I think a wee bit more understanding and support of policies, at a governmental level, but also within the workplace." \#12

Interestingly, not only were work family policies deemed as important but also the workplace culture. One father described how he found it easier to take time off, in his opinion, not because of the policies but because he worked in a predominately female workplace and because they took time off, he was also able to:

"I think if I worked in somewhere like the shipyard, or a factory or as a mechanic where there are predominately men I don't think it would be feasible. I think it's really because it's who I work with, predominately with women who take off quite regularly. Say a colleague is off on dependant leave, well they can't turn round to me and say well, she can have off but you can’t...” \#11

\section{Discussion}

This study set out to explore men's expectations and perceptions of fathering, their perceptions of themselves as fathers, men and workers and how these perceptions relate to their behaviour as fathers. Our findings illustrated a range of meanings and expectations attached to notions of a 'good father'; from traditional understandings of fathers as breadwinners and providers, to more highly involved conceptualisations of fathers as active parents. Our findings corroborated a diversity of the fathering experiences and variability in commitment to the role in line with previous research (Lewis and Lamb, 2007). The findings speak to how perceptions of 
fatherhood are linked to and influenced by men’s normative views of the male role within the family and in wider society. Clear interplay between work and family roles was evident in those that subscribed to both traditional and modern notions of fatherhood. In direct contrast to the literature relating to motherhood (Gregory \& Milner, 2008), where women report viewing their work and family roles as independent, our fathers viewed the roles very much as interdependent, in that their role as a worker helped them fulfil their role as a father. As a consequence, there was clear evidence that men reported many advantages to combining work and family roles, something which is less often reported in the literature on working mothers.

Also apparent throughout the interviews was the widespread understanding of the new ideals of fatherhood. These new fatherhood ideals were not always seen as compatible with traditional definitions of masculinity and fathering. Consistent with Halford (2006), there seemed to be a significant gap between the fatherhood ideals and actual fathering practices for some of the fathers. This gap between idealised father behaviour and father's everyday reality was justified in a number of ways. One which dominated was the notion that mothers were inherently better at caring for children than fathers. A corollary of this finding was the frequent conflation of the role of father and husband evident in the interviews. Fatherhood was often defined and referenced through the lens of wives and mothers. Normative views concerning gender roles were internalized and appeared to shape behaviour not only directly, but indirectly through the expectations that others will disapprove of behaviour which go against gendered expectations. Our findings points to a number of instances whereby participants reported approval or disapproval depending on whether or not their behavior was deemed gender role congruent. Indeed this was pointed out explicitly by one of the fathers who, in a peculiarly Irish 
and culture specific way, believed doing 'a woman's chores’ would mean fathers could face the ridicule of their peers in the pub!

Our findings also illustrated how a father's identity and expectations of their parenting role was related to their behaviour within that role. For instance, fathers who believed that a good father is synonymous with providing felt that they were adequately fulfilling their role as a father, by simply being in paid employment. Those fathers that viewed the father identity as being more involved described combining the roles as considerably more challenging. These fathers described the experience of being pulled in different directions and constantly having to juggle the competing demands of parenthood and paid employment. Key to understanding these variations appears to be the importance that men attach to their work, family and gender identities and the normative parameters associated with each identity. For example for those fathers who perceived that their worker identity was central to their sense of selves, balancing the demands of the two roles was unproblematic.

In some cases, it was clear that the worker identity had taken on central importance because of extraneous threats such as insecure employment or competition. In such cases, the importance of maintaining income for the family was prioritised over engagement with children, which was then seen as optional and at their discretion. Self-categorisation theory suggests that extraneous contexts effect our self definitions, and these contexts (for example being in or out of work) can also influence how we appraise ourselves as group members (good father/husband or bad father/husband). Available research evidence indicates that where such threats to important identities exist, individuals are more trenchant in their attitudes (Haslam, 2004; Muldoon \& Lowe, 2012). As such, willingness to break with traditional notions of the male role or fatherhood or engagement with activities associated with femininity or motherhood becomes less 
likely. Paradoxically, this is likely to have the greatest consequence for men who subjectively perceive unemployment as emasculating, making them less willing to engage with their children at a time when they have available time to do so. In times of financial crisis, therefore it may well be that regressive social change is facilitated by this process.

One potential way in which this effect could be countered is by focusing on the less well understood effects that behavior may have on identity (Cast, 2003). Whilst attention has been paid to the effect of identity on behavior, the potential for a process flowing in the alternate direction is less often considered. Cast argues that given that the self is a process which shapes and is shaped by interaction, it seems plausible that not only should identity affect behavior, but behavior in turn impacts on identity. This is particularly relevant to a debate about fathering, as Carbera et al (2000) point out, men do not father in a social vacuum. Thus the bidirectionality of the father-child relationship needs to be considered, and whilst much research has been conducted on the positive outcomes for the children, we know less of the impact on the father. Our findings illuminate this issue, in that fathers suggested that the more effort they put into their role of the father, the more they received out of it, which in turn served to alter their expectations and meaning of fatherhood. This was not confined to their own perceptions, in that some of the men perceived a positive change in how their colleagues and managers viewed them as a consequence of fatherhood. Thus for men, contributing more to the fathering role can help to change not only their own expectations but others around them.

Our study is limited in terms of sample size and demography (all respondents living in Northern Ireland), however our data collection, analysis and verification processes ensured saturation of the qualitative categories articulated here. Future research would benefit from including mothers' perspective on these issues, and more particularly dyad parent interviews 
which would allow the inter-relationship of father's and mother's practices to be more fully considered. Additional research should also consider the issues that arise for specific groups of fathers such as, low income and unemployed fathers or perhaps those looking after children with complex healthcare needs who face particular challenges.

Despite these limitations, our results illustrate the significance of identity processes in exploring how men view fatherhood and consequently negotiate their work and family lives. Our findings suggest that the new norms of fatherhood have reached fathers in our study and they are aware of the increased requirement upon them as fathers to engage with their children personally, emotionally and in everyday ways. However, despite the considerable social change in recent decades and significant change in how fathers parent, there remains a lingering gendered division of roles within the home. Our findings suggest that this may in part be attributable to the tensions that exist for fathers as they try to navigate the demands of their parenting, gender and occupational roles. This tension is writ large in those situations where the expectations of 'new fatherhood' conflict with other normative expectations. Being emotionally available and involved with the children is difficult where long hours are required to be viewed as a good worker and breadwinner, or where traditional masculinity is central to acceptance within a friendship network. The lack of institutional and cultural support for parents, the threat associated with insecure employment and the continuing disapproval of gender incongruent behavior remain important agenda items in the pursuit of egalitarian division of parenting, and a real shift towards 'new' parenting practices to the benefit of fathers, mothers and their children. 


\section{References}

Aumann, K., Galinsky, E. \& Matos, K. (2011). The new male mystique. New York: Families and Work Institute. Retrieved from http://familiesandwork.org.

Bronte-Tinkew, J., Moore, K. A., \& Carrano, J. (2006). The father-child relationship, parenting styles, and adolescent risk behaviors in intact families. Journal of Family Issues, 27(6), 850-881.

Carbera, N. J., Tamis-LeMonda, C. S., Bradley, R., Hofferth, S., \& Lamb, M. E. (2000). Fatherhood in the twenty-first century. Child Development, 71, 1, 127-136.

Cast, A. (2003). Identities and Behavior. In P.J. Burke, T.J. Owens, R.T. Serpe \& P.A. Thoits (Eds.), Advances in identity theory and research (pp. 41-56). New York: Kluwer Academic.

Coltrane, S. (2004). Fathering: paradoxes, contradictions and dilemmas. In M. Coleman and L. Ganong (Eds.), Handbook of contemporary families: Considering the past contemplating the future (pp. 224-243). Thousand Oaks, CA: Sage Publications.

Cook' J., Jones' R. M., Dick’ A. J. \& Singh, A. (2005). Revisiting men’s role in father involvement: The importance of personal expectations. Fathering: A Journal of Theory, Research, and Practice about Men as Fathers, 3, 2, 165-178.

Cousins, C., \& Tang, N. (2004). Working time and work and family conflict in the Netherlands, Sweden and the UK. Work, Employment and Society, Volume 18, 3, 531-549.

Craig, L., \& Bittman, M. (2004). The effect of children on adults. Time-use: analysis of the incremental time costs of children in Australia. Paper presented at the workshop, Supporting children, English-speaking countries in international context, Princeton University, January 7-9, 2004. 
Daly, K. (1993). Reshaping fatherhood: Finding the models. Journal of Family Issues, 14, 4: 510-530.

Daly, K., \& Palkovitz, R. (2004). Guest editorial: Reworking work and family issues for fathers. Fathering: A Journal of Theory, Research, and Practice about Men as Fathers, 2(3), 211-213.

Este, D. C. \& Tachable, A. (2009). Fatherhood in the Canadian context: perceptions and experiences of Sudanese refugee men. Sex Roles, 60, 456-466.

Glaser, B. G., \& Strauss, A. I. (1967). The discovery of Grounded Theory; Strategies for qualitative research. New York, Aldine.

Gregory, A. \& Milner, S. (2009). Work-life balance: A matter of choice? Gender, Work \& Organization, 16, 1, 1-13.

Harrington, B., Van Deusen, F., \& Humberd, B. (2011). The new dad: Caring, committed and conflicted. Boston, MA: Boston College Centre for Work and Family.

Halford, S. (2006). Collapsing the boundaries? Fatherhood, organization and homeworking. Gender, Work and Organization, 13, 4, 383-402.

Haslam, S.A. (2004). Psychology in organizations: The social identity approach (2nd ed). London: Sage.

Henley, K., \& Pasley, K. (2005). Conditions affecting the association between father identity and father involvement. Fathering: A Journal of Theory, Research and Practice about Men as Fathers, 3, 1, 59-80.

Henwood, K.L., \& Procter, J. (2003). The ‘Good Father’: Reading men’s accounts of paternal involvement during the transition to first time fatherhood. British Journal of Social Psychology, 42, 337-355. 
Janzen, B. L., \& Kelly, I. W. (2012). Psychological Distress Among Employed Fathers Associations With Family Structure, Work Quality, and the Work-Family Interface. American Journal of Men's Health, 6(4), 294-302.

Lachance-Grzela, M., \& Bouchard, G. (2010). Why do women do the lion’s share of housework? A Decade of Research. Sex Roles, 63, 11-12, 767-780.

Laurijssen, L.I. \& Glorieux, I. (2013). Balancing Work and Family: A panel analysis of the Impact of Part-time work on the experience of time pressure. Social Indicators Research, $112,1,1-17$.

Lewis, C., \& Lamb, M. E. (2006). Fatherhood: Connecting the strands of diversity across time and space. York: Joseph Rowntree Foundation.

Lewis, C. \& Lamb, M.E. (2007). Fatherhood: Connecting the strands of diversity across time and space Chapter in 1-35: Parenting: research and development. http://www.jrf.org.uk/sites/files/jrf/understanding-fatherhood.pdf.

Lincoln, Y. S., \& Cuba, E. G. (1985). Naturalistic Enquiry. Beverley Hills: Sage. Lobel, S., \& St. Clair, L. (1992). Effects of family responsibilities, gender, and career identity salience on performance outcomes. Academy of Management Journal, 35, 1057-1069.

Mannino, C., \& Deutsch, F. (2007). Changing the division of household labor: A negotiated process between partners. Sex Roles, 56, 309-324.

Matta, D. S., \& Knudson-Martin, C. (2006). Father responsivity: Couple processes and the coconstruction of fatherhood. Family Process, 45(1), 19-37.

McBride, B. A., Brown, G. L., Bost, K. K., Shin, N, Vaughn, B., \& Korth, B. (2005). Paternal identity, maternal gatekeeping, and father involvement. Family Relations, 54, 360-372. 
Muldoon, O. T., \& Lowe, R. D. (2012). Social Identity, Groups, and Post - Traumatic Stress Disorder. Political Psychology, 33(2), 259-273.

McLaughlin, K., Muldoon, O. T., \& Moutray, M. (2010). Gender, gender roles and completion of nursing education: a longitudinal study. Nurse Education Today, 30(4), 303.

Muldoon, O., McLaughlin, K., \& Trew K. (2007). Adolescents’ perceptions of national identification and socialisation: A Grounded Analysis. British Journal of Developmental Psychology, 25, 579-594.

Nicolson, P. (1996). Gender, power and organization: A psychological perspective. London: Routeledge.

O’Brien, M. (2004). Social science and public policy perspectives on fatherhood in Europe' in M. E. Lamb (ed.), The role of the father in child development (4th ed.). New Jersey: Wiley.

O’Brien, M. (2005). Shared caring: Bringing fathers into the frame. London: Equal Opportunities Commission.

Olmstread, S.B., Futris, T.G. \& Pasley, K. (2009). An exploration of married and divorced, nonresident men's perceptions and organization of their father role identity. Fathering: A Journal of Theory, Research, and Practice about Men as Fathers, 7, 3, 249-268.

Pasley, K., Futris, T. G., \& Skinner, M. L. (2002). Effects of commitment and psychological centrality on fathering. Journal of Marriage and the Family, 64, 130-138. Pleck, J.H., \& Masciadrelli, B.P. (2004). Paternal Involvement by U.S. residential Fathers: levels, sources and consequences. In M.E. Lamb (ed.), The role of the father in child development (4th ed.). Hoboken, NJ: John Wiley \& Sons. 
Pomper, D. (2010). Masculinities, the metrosexual, and media images: Across dimensions of age and ethnicity, Sex Roles, 63, 682-696.

Prentice, D. A., \& Carranza, E. (2002). What women should be, shouldn't be, are allowed to be, and don't have to be: The contents of prescriptive gender stereotypes. Psychology of Women Quarterly, 26, 269-281.

Ranson, G. (2012). Men, paid employment and family responsibilities: Conceptualizing the ‘working father'. Gender, Work \& Organization, 19(6), 741-761.

Reicher, S. D. (1984). The St. Pauls' riot: an explanation of the limits of crowd action in terms of a social identity model. European Journal of Social Psychology, 14(1), 1-21.

Sagi, A. (1982). Antecedents and consequences of various degrees of paternal involvement in child-rearing: The Israeli project. In M. E. Lamb (Ed.), Nontraditional families: Parenting and child development (pp. 205-232). Hillsdale, NJ: Erlbaum.

Schreider, R. (2001). The ‘how to’ of Grounded Theory: Avoiding the pitfalls. In R. Schreiber and P. Stern (Eds.), Using Grounded Theory in Nursing (pp. 55-84). New York: Springer.

Shelton, B. A., \& John, D. (1996). The division of household labor. Annual Review of Sociology, 22, 299-322.Strauss, A., \& Corbin, J. (1998). Basics of Qualitative Research. 1998. Thousand Oaks.

Stryker, S. (1987). The interplay of affect and identity: Exploring the relationships of social structure, social interaction, self, and emotion. Paper presented at social psychology section, American Sociological Association, Chicago.

Stryker, S., \& Serpe, R. (1982). Stability and change in self: A structural Symbolic Interactionist explanation. Social Psychology Quarterly, 50, 44-55. 
Yavas, O., Babakus E., \& Karatepe, O. M. (2008). Attitudinal and behavioral consequences of work-family conflict and family-work conflict. Does gender matter? International Journal of Service Industry Management, 19:7-31. 
Father Identity and Work Family Balance 32 